\title{
Article
}

\section{The Elephant in a Dark Room? Russia and the ISDS Reform}

\author{
Dmitry K. Labin* \& Alena V. Soloveva**
}

The calls for reform of investment treaty regime are neither novel nor entirely unexpected. And the need for that reform has recently reached its pitiful nadir where the UNCITRAL Working Group III gathered for its first meeting in Vienna back in November-December 2017 to discuss states' concerns about investor-state dispute settlement. States' concerns about the reform have been repeatedly referred to in recent publications, but international scholars have not yet discussed Russia's stance in detail. In the following an attempt has been made to fill the gap in literature by introducing the Russian position which contrasts nicely with Canada or the EU. Why is this important? Russia is a significant state in the UNCITRAL Working Group III and any slight shifts in its approach in the UNCITRAL reforms are closely watched. It is the right time to provide an analytical framework for understanding the Russian position in these reform dynamics.

Keywords: ISDS Reform, UNCITRAL, Russia, Investment Treaty Arbitration

* Professor of International Law at MGIMO University - Moscow, Russia; Editorial board member of the Moscow Journal of International Law, J.D. in International Private and Public Law (MGIMO), Ph.D. \& Doctor of Laws (Institute for State and Law of the Russian Academy of Sciences). ORCID: http://orcid.org/0000-0002-1493-4221. The views reflected in this article are the author's own. The author may be contacted at: d.labin@inno.mgimo.ru/Address: MGIMO, 76 Prospekt Vernadskogo, Moscow 119454, Russia.

** Ph.D. candidate at MGIMO University - Moscow, Russia; Associate at an international law firm Kennedys (Moscow, Russia), B.A. (MGIMO), LL.M. (UCL). ORCID: http://orcid.org/0000-00022142-7666. The views reflected in this article are the author's own. The author may be contacted at: helena.soloveva@gmail.com/Address: MGIMO, 76 Prospekt Vernadskogo, Moscow 119454, Russia.

All the websites cited in this article were last visited on July 31, 2020. 


\section{INTRODUCTION}

The calls for reforming the investment treaty regime are neither novel nor entirely unexpected. The need for that reform has recently reached its pitiful nadir where the UNCITRAL ${ }^{1}$ Working Group III gathered for its first meeting in Vienna back in November-December 2017 to discuss states' concerns about investorstate dispute settlement (ISDS). These discussions constitute one of the most remarkable occurrences in the field of investment treaty arbitration. Of still greater significance are concerns advanced by the delegates about consistency, predictability and correctness, costs and transparency, facts and perceptions, appointment of arbitrators, etc.

States' concerns about the reform have been repeatedly referred to in recent publications, ${ }^{2}$ but international law scholars have not yet discussed Russia's stance in detail. Then, an attempt has been made to fill the gap in the literature by introducing the Russian position which contrasts with some other approaches, for instance, of Canada or the EU. For this reason, our account requires that we discuss in closer detail several (most controversial) statements advanced by Russian delegates and substantiate them with doctrinal and practical evidence to shed light on the reasoning behind those statements.

This article seeks to analyse the issues of transparency and third-party participation in the arbitral proceedings, focusing on the amicus curiae mechanism. The authors will provide a broad overview of commercial arbitration in the context of investment arbitration and Russia's incrementalist position with respect to the ISDS reform as exhibited through the delegates' statements on the dichotomy of facts and perceptions, coherence and consistency, and appointment of arbitrators. The article also traces recent swift normative developments in investment policy of Russia, which demonstrates the country's unique perspective on ICSID membership.

\section{RuSSIA IN THE UNCITRAL WoRKING GROUP III}

\section{A. Transparency}

Delving into current debates surrounding the importance of transparency, the 
authors begin with a notion that Russia seems to be one of the states that is most sceptical and reluctant to make efforts for a more multilateral and transparent system, viewing the criticisms of the current system as mainly overblown. Those who have not participated in the UNCITRAL Working Group III meetings as an Observer can benefit from the readily available audio recordings of the past meetings. ${ }^{3}$ On a separate note, while Russia took a rather active position in the reform discussions during the 34th and 35th meetings, it remained surprisingly mute in the 36th meeting and only advanced some commentaries on the last day of the Working Group session.

In the course of discussing the nature of transparency in the context of investment arbitration, it is first necessary to highlight the rationale and key features of this concept which must be approached with due diligence and care. The values of confidentiality and transparency are often invoked in the theory and practice of investment treaty arbitration. In a general sense, the term "transparency" is not immediately associated with international law. Yet, it has gained popularity and "became a foundation of international law" in large part due to the active participation of public and non-governmental organisations (NGOs) in global governance. ${ }^{4}$ Transparency is an evolving concept. Since the 2000s, it has received "increasing recognition in international dispute settlement processes." "transparency" in international investment law connotes that "host states have an obligation to publish all of the legal rules, regulations and other statutory requirements affecting investors."

The Working Group III undertook its expected consideration of transparency in ISDS. Throughout the deliberations, the importance of transparency in ISDS was actively underlined. There is no lack of major variation as transparency is regarded by many as a key element of the rule of law, access to justice as well as the legitimacy of the ISDS system. ${ }^{7}$

There are different ways to address the lack of transparency. As a very modest starting point, enhanced transparency in the current ISDS system may be achieved through transparency in the appointment of arbitrators and their compensation. ${ }^{8}$ A broader concept of transparency is indeed cross-cutting and relates to many aspects of the possible ISDS reform.

On this issue, Russia vividly commented that the key to the solution can be found in bilateral or multilateral investment treaties or in the relevant arbitral rules. 
Therefore, transparency shall be ensured by states in line with their geopolitical and regional needs. And this in turn is the main advantage of investment treaty arbitration. Furthermore, transparency is a multi-layered problem. On the one hand, there have been ever-increasing calls for enhanced transparency of arbitral proceedings. On the other hand, from a state perspective, most arbitral proceedings tend to involve sensitive information which may potentially concern national security. Likewise, investors may also possess information which they will not be happy to share with the general public. As a result, there is a fine line between transparency requirements and protection of the legitimate interests of disputing parties. Russian delegates expressed their genuine surprise when they learned that this aspect appeared unpopular with other delegates and had not been mentioned in the document which served as a base for the Working Group III considerations of transparency in ISDS. ${ }^{9}$

Russia made it to the top ten of the most frequent respondent States in 19872017 with the total number of known cases reaching 24. Of these, 18 cases represent arbitrations under the UNCITRAL Arbitration Rules. ${ }^{10}$ Although a higher degree of transparency is considered to be a distinguishable feature of investorstate arbitration, the 1976 and 2010 editions of the UNCITRAL Arbitration Rules did not contain any specific provisions on transparency. Thus, if a state or investor were unwilling to publish documents connected with a dispute, it would be almost impossible to do so. ${ }^{11}$ For example, in Cesare Galdabini v. Russian Federation, ${ }^{12}$ the award (in favour of Russia) was never published. Similarly, in Luxtona v. Russia ${ }^{13}$ and Oschadbank v. Russia, ${ }^{14}$ no information is available to the public to date. Incidentally, in the infamous Yukos Universal v. Russia, ${ }^{15}$ some 25 documents including legal and expert opinions remain closed to the general public. In a more recent closely-watched UNCITRAL case, Privatbank and Finilon $v$. Russia ${ }^{16}$ observers can only benefit from press releases by the Permanent Court of Arbitration (PCA).

Russia has underperformed as a home state of claimants with only 22 known cases submitted by Russian investors. Again, more than 50 percent of those cases represent arbitrations under the UNCITRAL Arbitration Rules. A further overview reveals that in 11 cases decisions are pending with the oldest case dating to $2007 .{ }^{17}$ Of the remaining cases, three were discontinued and one was settled. By way of simple arithmetic, there are only seven cases where an actual decision has been 
rendered. And in three cases, the awards have not been published. Surprisingly, some cases do not even disclose information about the tribunal composition. ${ }^{18}$ In 2016, Russian investors became more active ${ }^{19}$ initiating most disputes under the UNCITRAL Arbitration Rules with the only ICSID $^{20}$ claim filed by subsidiaries of a Russian corporation. ${ }^{21}$

The UNCITRAL Arbitration Rules were revised in 2010 and 2013, respectively. A number of provisions were updated in 2010 to improve procedural efficiency. The adoption of the UNCITRAL Rules on Transparency in Treaty-based InvestorState Arbitration (hereinafter Rules on Transparency) triggered an additional revision of the UNCITRAL Arbitration Rules in 2013, with a new Article 1(4) providing for the application of the Rules on Transparency which came into effect on April 1, 2014. The Rules on Transparency comprise procedural rules on transparency, public access to investment treaty arbitration, and a full disclosure of most documents to the public. ${ }^{22}$

The Rules on Transparency have been incorporated in most investment treaties concluded since their entry into force. In addition, there is a brand-new transparency-dedicated legal instrument - the United Nations Convention on Transparency in Treaty-based Investor-State Arbitration (hereinafter Mauritius Convention), which was signed by twenty-two States and entered into force on October 18, 2017, after having been ratified by three States. ${ }^{23}$ Incidentally, Russia is not even a signatory to the Mauritius Convention. This examination is especially valuable given that in 2016 the Government of the Russian Federation enacted the Regulation on Entering into International Treaties on the Encouragement and Mutual Protection of Investments (Regulation 2016), ${ }^{24}$ which replaced the 2001 Russian Model Bilateral Investment Treaty (BIT) and contains nonbinding guidelines for drafting and negotiating future investment protection treaties. Importantly, the 2016 Regulation specifies that any new investment treaty should expressly exclude the UNCITRAL Rules on Transparency and establish a duty of confidentiality with respect to any information about the dispute. This "concept of privacy and confidentiality originates primarily from the foundational underpinnings of international commercial arbitration, but it has also to a considerable extent been translated into the investment context." ${ }^{25}$ This explains the rationale for Russia's visible reluctance to support concern about enhanced transparency in the ISDS system. 


\section{B. Amicus Curiae}

Amicus briefs are an ancient legal instrument, originating in Roman law and gradually taking over the common law tradition and civil law jurisdictions. ${ }^{26}$ Recent decades have seen a significant increase in the number of legal dispute settlement mechanisms, which has opened the door for NGOs to participate as "friends of the court" (amicus is a "friend of the court"). Such participation has been visible, in particular, in international investment arbitration. ${ }^{27}$ Initially, only NGOs have submitted their amicus briefs in investment arbitration. This practice has lately shifted to include home states, international communities, and even individuals as amici curiae. ${ }^{28}$ However, despite these interesting developments, "direct NGO participation in international courts and tribunals generally remains relatively limited, so that their participation remains essentially a matter of domestic litigation." ${ }^{29}$ The concept of amicus curiae is accepted in common law and even some civil law jurisdictions. ${ }^{30}$ On the domestic level, amicus intervention has frequently involved a range of participants, including individuals and foreign governments. ${ }^{31}$ Amicus participation ordinarily takes the form of written submissions, ${ }^{32}$ but oral hearings may also be arranged. ${ }^{33}$ Therefore, the purpose and form of amicus briefs have not been stable across time and jurisdictions. In the US, for example, amicus briefs have shifted "from a source of neutral information to a flexible tactical instrument available to litigants and third parties. ${ }^{34}$

Investment arbitration tribunals initially refused to allow third-party participation. ${ }^{35}$ In Aguas del Tunari S.A. v. The Republic of Bolivia (known as the Bechtel case $)^{36}$ the tribunal denied citizens and environmental groups standing at the arbitration due to the parties' unwillingness to consent to their participation. In recent, however, there has been an "undeniable shift in investor-State arbitration toward greater tolerance of limited third-party participation, perhaps in response to continuing public pressure and criticism. ${ }^{, 37}$

The rapid rise to prominence of international investment arbitration has been accompanied by "mounting public concern about the system's legitimacy and accountability. ${ }^{, 38}$ Commentators and civil society groups have called for increased public involvement in investment arbitration to incorporate broader policy considerations and add transparency. ${ }^{39}$ In a similar vein, transparency is closely associated with amicus curiae which includes "measures such as the publication of information on proceedings, documents and awards, as well as attendance at 
and broadcasting of hearings." ${ }^{40}$ In this sense, acceptance of receiving amicus curiae briefs in international investment law is commonly perceived as "a ground-breaking development and without a doubt paves the way to enhanced transparency in these proceedings." ${ }^{41}$

In the fifteen years since amicus briefs were first admitted in investor-state arbitrations, they have emerged as the principal means through which NGOs have been able to participate formally in arbitration proceedings. Russia's criticism has initially focussed on the alleged impact that home states may exert on decisionmaking in favour of foreign investors via NGOs as amici curiae. This in turn may lead to politicisation of the entire process.

There may be some ground for Russia's exhibition of frustration. It has generally been accepted that the main function of amicus curiae submissions is to assist the tribunal in its work "by offering expertise and arguments different from those of the disputing parties." ${ }^{, 42}$ Investment tribunals have been flexibly accepted that "third-party submissions could in fact contain useful information.", It should be emphasised that NGO participation through amicus curiae briefs is merely an "indirect form of participation, which perhaps does not warrant such profound apprehension." ${ }^{44}$ Logically, the participation cannot be equated with that as a party to the disputes. ${ }^{45}$ Hence, those states who are a party to a dispute remain

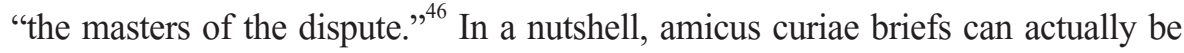
considered as very much equivalent to publicly available information (which is consistent with the treatment of amicus curiae briefs by the International Court of Justice). ${ }^{47}$

A quick example should illustrate the problem explicitly invoked by Russia. In February 2016, the tribunal in Eli Lilly made decisions on nine applications to file amicus briefs submitted by a total of twenty-five parties. ${ }^{48}$ These parties included NGOs, individuals and industry associations. The six briefs that were eventually accepted focussed on the legality of certain Canadian patent laws. Canada, as a respondent State in the dispute, complained that the claimant was a member of two industry associations that had applied to file amicus briefs. ${ }^{49}$ On a more technical level, the tribunal found that a disputing party's membership in an amicus curiae does not mean a lack of independence of the amicus per se. Instead, such membership should be viewed "in relation to the tribunal's consideration of the extent to which the amicus brief would assist the tribunal in determining a factual 
or legal issue related to the arbitration by bringing fresh perspective, knowledge or insight. ${ }^{, 50}$ The tribunal proceeded to admit the briefs of the two amici.

The participation of NGOs in ISDS has been noticeable principally in cases involving matters of public interest, namely "in cases relating to the environment and water in their connection with trade and foreign investment. ${ }^{, 51}$ In that sense, NGO participation is not necessarily to the benefit of the tribunal, but rather to the benefit of a greater "public interest," since the participation "increases the legitimacy, transparency and openness of international investment arbitration and international economic dispute settlement. ${ }^{, 52}$

The involvement of NGOs as amici in international proceedings has been sharply contested. Debate concerning the proper role of NGOs in international investment arbitrations has been "particularly intense." ${ }^{, 53}$ Supporters claim that amicus activity by NGOs helps remedy deficits of participation and legitimacy at the international level. ${ }^{54}$ Keeping such benefits in mind, some commentators have cited amicus activity as "a component of evolving global administrative law norms. $"$ " Opponents (including many developing countries) argue that amicus participation by NGOs gives these organisations too much influence and "unfairly benefits developed countries." ${ }^{, 56}$ To the extent that common law correlates with economic development, ${ }^{57}$ the common law origins of amicus activity also map onto this dispute. One commentator has stated that "the introduction of amici participation into investment arbitration may be seen as representing a victory of common law over civil law, and of the developed world over the developing world., ${ }^{58}$

Linked to these concerns, it is indeed "difficult to measure directly the influence of amicus briefs on the determinations of tribunals. ${ }^{, 59}$ As might be expected, no tribunal has expressly stated the amount of influence (or lack thereof) that an amicus brief has had on the tribunal's reasoning ${ }^{60}$ which makes it difficult to assess the validity of Russia's concerns about NGO participation in ISDS. However, it is possible to draw some cautious conclusions based on other factors, such as how often, where and in what ways a tribunal refers to an amicus brief in an award.

Investment tribunals have elaborated three approaches to the contributory value of amicus briefs. First, some commentators conclude that amici have had little influence on tribunals. In relation to amicus briefs on human rights issues 
submitted between $2011^{61}$ and $2012,^{62}$ for instance, previous scholarship has suggested that "tribunals have been much more selective when referring to amicus briefs in their substantive reasoning," but sometimes they did not observably employ even detailed and well-founded arguments, and sometimes explicitly ignored them. ${ }^{63}$

Second, other commentators conclude that tribunals have been influenced to some degree by amicus briefs, but without express reference in their awards. Support for this view may be derived from tribunals' comments on the utility of a brief. For example, in Biwater Gauff, ${ }^{64}$ the tribunal found the amici's observations useful. The case in which amicus briefs have been most influential is Philip Morris. ${ }^{65}$ The ICSID tribunal referred throughout its award to submissions from the World Health Organization and the Pan-American Health Organization to support its findings on the merits of the case. ${ }^{66}$ However, the amici's submissions were mainly factual and focussed on the efficacy of certain policies on public health issues, rather than legal arguments. This indicates that "amicus interventions are more likely to be influential where they focus on matters falling outside of the expertise of the tribunal (or the expertise of the disputing parties)., ${ }^{, 67}$

Finally, an alternative view is that tribunals "only permit influence where there is something special either about the points made or the amicus itself., ${ }^{, 68}$ This view may explain the greater degree of attention tribunals seem to have accorded to the European Council in cases involving intra-EU BITs since the EC is distinguishable from traditional amici (NGOs) in its role as the "expert, administrator, enforcer and a maker of, EU law." ${ }^{69}$ However, greater attention does not necessarily mean greater success, and tribunals have rarely taken EC points into consideration. ${ }^{7}$

While increasing acceptance of amicus curiae in ISDS, there is a notable countervailing concern about the potential effects on such an approach including increased costs and delays in proceedings. This is demonstrated by tribunals' exercise of their broad procedural authority to reject applications for lateness, circumscribe the length and content of briefs, and reserve the right to impose costs upon amici. Despite these concerns, certain tribunals, treaty drafters and authors of arbitral rules are not averse to having more amicus briefs per se.

However, a question may remain about the frequent categorisation of amicus participation as a transparency measure which may not always be entirely appropriate. This participation itself can often be a "one-way affair,", where a 
brief is filed without the amicus learning anything new about the case. Thus, there are also disadvantages to being an amicus. ${ }^{72}$ Unlike parties, amici cannot control the direction of a dispute or case management; they are not generally served case documents and cannot offer evidence, examine witnesses or cross-examine them. ${ }^{73}$

This conundrum has practical relevance since objections to amicus participation, such as inefficiency, are sometimes viewed as applicable to transparency in general. Another interesting issue is whether transparency measures in investment arbitration might spill over into international commercial arbitration. The transparency debate "certainly is not new to commercial arbitration." " However, transparency has not gained the same amount of traction in this sphere since commercial arbitration is predominantly "a matter between private parties and therefore should not be subject to public scrutiny." Although a comprehensive discussion is beyond the scope of this article, this is certainly something to watch "given the apparent present appetite for institutional and legislative reform."

\section{Holistic Approach to Procedural Reform}

Each element has its advantages and disadvantages. And in order to accurately appreciate the significance of ISDS, both sides of the coin shall be equally respected and inspected. Otherwise, it would appear that the whole system of ISDS is painted only with dark shades which in turn produces a perverted landscape with rather sad scenery. Reality of course is more complex and nuanced. To underscore the importance of a balanced and holistic approach to procedural reform, Russia urged the Secretariat to request comments from the major arbitration centres in London, Stockholm, Singapore, and Hong Kong. Incidentally, the Secretariat responded that discussions had been conducted only with those heavily involved in ISDS (including the ICSID and the PCA), but not with commercial arbitration centres. Yet, Russia mentioned commercial arbitration because these centres administer a significant number of arbitrations, and their experience would thus bring significant value given their status as most preferred arbitral institutions. ${ }^{77}$

Historically, the rise of investment treaty arbitration attracted not only those active in the field, but also practitioners "who did not have a background in public international law, but in international commercial arbitration" ${ }^{78}$ largely because applicable procedural law was "either the same as that applicable to commercial arbitrations, as in the case of investment arbitrations under UNCITRAL 
Arbitration Rules, the Arbitration Rules of the Arbitration Institute of the Stockholm Chamber of Commerce (SCC Rules), or the Rules of the International Chamber of Commerce (ICC Rules), or modelled on commercial arbitration procedure, as in the case of ICSID arbitrations."

Accordingly, international investment law is more characterised by a division between those from private commercial law and arbitration, and those from public international law and inter-state dispute settlement. ${ }^{80}$ This naturally results in a "veritable culture clash" 81 that can be traced in the ongoing reform discussions. Private commercial and public international lawyers are known to have different perspectives on the function of dispute resolution. Whereas public international lawyers "embed international investment law firmly in general international law, commercial arbitration lawyers see investment treaty arbitration as a subset of international (commercial) arbitration." ${ }^{, 82}$

As this discussion suggests, "investment arbitral proceedings frequently rely on the same procedural rules that govern commercial arbitration, and contain certain privacy and confidentiality rights." ${ }^{83}$ Thus, the UNCITRAL Arbitration Rules, which are frequently used in investment arbitration disputes, restrict the publication of any awards without the parties' consent. ${ }^{84}$ In this regard, there are also similar confidentiality rights in the "investment-specific ICSID regime., For instance, the ICSID Convention prohibits publication of the award without the consent of the parties. ${ }^{86}$ As such, institutional rules have traditionally provided disputing parties with the advantage of "fashioning the investment arbitration proceedings to preserve privacy and confidentiality., 87

Certainly, the classification into public international law and commercial arbitration approaches is "no more than a blueprint or archetype." 88 Yet, education, professional background, and practical experience will inevitably facilitate a certain mind-set in line with either public international law or commercial arbitration archetype. ${ }^{89}$ This is visible, for example, in the different sources arbitrators with a commercial arbitration background and those with a public international law background who make reference to in the awards, ${ }^{90}$ in the chosen reasoning and preferred methods of interpretations, ${ }^{91}$ and in their respective understanding of the role of arbitrators and dispute settlement. ${ }^{92}$

What we now understand to be Russia's resistance to accept any modifications of investment treaty reform stems from the scholarly-backed preference for 
private international law over public international law. Russia's tendency to favour commercial arbitration originates from a lifelong characterisation of international investment law as a form of private international law rather than public international law which explains Russia's reluctance to join the movement toward more public international law measures. ${ }^{93}$ The existing system is built predominantly on international commercial arbitration, which has traditionally rejected transparency as an essential ingredient of dispute settlement. Hence, Russia's resistance which discords with the American, European, and Canadian approaches to the UNCITRAL reforms is largely due to an expressly manifested need for "greater legitimacy and public participation in international investment arbitration, as distinct from commercial arbitration." ${ }^{94}$

\section{Russia’s Dogmatic CaMP}

It is now axiomatic that there are three main dogmatic camps based on their approaches toward the ISDS reform: incrementalists, systemic reformers, and paradigm shifters. ${ }^{95}$ Some commentators have opined that Russia belongs to the incrementalist group which views the criticisms of the current system as unfairly exaggerated and argues that "investor-state arbitration remains the best option available." ${ }^{96}$ Hence, they favour retaining the existing dispute resolution system with only modest reforms that would redress specific concerns.

It can undoubtedly be noted that Russia has taken a remarkable pro-investorstate arbitration position consistent with incrementalism. Another issue to consider in evaluating Russia's commitment to the incrementalist camp concerns its attempts to challenge the severity of current ISDS problems such as inconsistency. Thus, Russian delegates have insisted that inconsistency is an advantage of the system rather than a disadvantage which helps ensure regional interests and political relations between countries. The delegates expressly argued in favour of the existing ISDS system with only targeted reforms addressing specific concerns modestly. In doing so, Russia is keeping true to its incrementalist approach and conceptualisation of the international investment system as a form of private international law.

In the international investment agreements (IIAs) signed in recent years, 
countries have implemented a large number of ISDS reform elements. Nearly all IIAs concluded in 2018 contain at least one, and most contain several, mapped ISDS reform elements. Against this background, within the Commonwealth of Independent States (CIS), no major ISDS policy shifts have occurred. ${ }^{97}$ To illustrate, the Eurasian Investment Agreement 2008, signed by Belarus, Kazakhstan, Kyrgyzstan, Russia and Tajikistan, does not contain ISDS reform elements or procedural improvements. ${ }^{98}$

Incrementalists tend to question the severity of the existing system's problems by suggesting, for instance, that "the concerns about inconsistent decisions are a natural and positive consequence of the bilateral nature of investment treaties." 99 Thus, Russia argued that it is "an advantage of the system and not a disadvantage." ${ }^{100}$ In the following discussion, three related concerns, individually or in combination, have been offered to explain Russia's incrementalist position showcased in the reform discussions. Incidentally, Russia has never commented substantially on the establishment of a multilateral investment court.

\section{A. Facts v. Perceptions}

Russia's position vis-à-vis perceptions requires an evidence-based approach. The UNCITRAL is tasked primarily with improving international trade law rather than working with public opinion. Perhaps, if there are indeed problems with the perceptions of the current ISDS system, there are doubts as to its objectivity and efficiency. But the issue of perceptions is a subjective one. While perceptions should be taken into consideration, there is no need to overemphasise their importance. If, in a particular state, an investment agreement with a stipulated arbitration mechanism has been publicly criticised, that government is advised to explain the criticised agreement to the general public the rationale. It does not necessarily imply that the international community must reshape the existing system, which could also be perceived negatively by that general public. Global concerns require global solutions. However, there is no persuasive reason to design global solutions to a local concern.

Most concerns would benefit when supported with facts, i.e., some verifiable data proving that a particular concern is a product of a particular system. A review of current trends reveals that there is, at present, no formalised or predictable process to address the interplay of these issues. Although this approach should 
be adopted with caution, it appears to represent an appropriate balance between addressing negative perceptions and facts, thereby enhancing the systemic legitimacy of ISDS.

\section{B. Consistency and Predictability}

Russian delegates have described the current system as piecemeal emphazing the need to streamline the application of standards in a practical context. The system is not uniform but even fragmentary. IIAs are an agreement between parties, so that the divergence in terms of the content of such agreements is natural. But it appears that this is not a problem of the system as a whole, or arbitration as a dispute settlement mechanism. As such, this problem is intrinsic to the application of various standards. For instance, there may be issues with respect to the qualification and expertise of the arbitrators appointed by parties. In this regard, this is essentially a problem of those arbitrators, rather than the system.

Inconsistency is both a weak and strong point of the ISDS system. An additional reason supporting this statement is that the absence of a universal system helps better accommodate states' regional interests. Each agreement is a result of a negotiation process which includes political questions, trade system concerns, and distinct elements of national legal systems. Therefore, the ability to design the customised content of an agreement is a disadvantage, but an advantage of the system. Rulemaking may be "haphazard, messy, and uneven, depending on what is needed and what is feasible in a given constellation of interests and forces." ${ }^{101}$ These rationales for divergence play out in different combinations and to differing degrees with respect to states' regional ambitions.

Highlighting the importance of a practical solution to inconsistency, Russia has underscored the general nature of the arguments of the delegates because one particular arbitration relates to one particular treaty applicable to particular states, but not to the whole system. ${ }^{102}$ Therefore, it is a huge misperception of reality to claim that different decisions are being rendered in different corners of the world. Russian delegates argue that it is hardly feasible to arrange a uniform and unified system since IIAs are different per se. Consistency, therefore, shall be ensured in a practical context, which is a problem for a particular agreement and particular arbitrators, rather than the overall system. 


\section{Arbitrator Appointments}

Throughout the reform discussions Russia has repeatedly emphasised the need to gather opinions from commercial arbitration centres in relation to the appointment of arbitrators as this will make the reform discussions comprehensive and integrated. Russian delegates believe that it is wrong to say that a system where parties assume the responsibility to appoint arbitrators, does not ensure impartiality and independence. The problem does not lie in the appointment mechanism, but guaranteed compliance by arbitrators with the requirements. ${ }^{103}$

Perhaps even more surprising than the frequency of such arguments is that the appointment of arbitrators became the only concern which gained Russia's attention in the 36th meeting of the UNCITRAL in Vienna. Generally speaking, Russia shared the general concern about compliance with the standards of independence and impartiality of arbitrators, but questioned the need for a code of ethics for arbitrators. Also, Russia asked for statistical data which would prove that arbitrators decide in favour of an appointing party. ${ }^{104}$ This is a significant issue in its own right. A commonly-held belief has been that investment arbitrators, in an effort to please both parties and to win repeat appointments, often issue compromise decisions that will to some extent satisfy each party. ${ }^{105}$ Another frequently-held belief maintains that investment arbitrators are usually biased against the respondent State and are more inclined to decide in favour of investors. ${ }^{106}$ However, occasional studies ${ }^{107}$ tend to reject both of these common beliefs: investment arbitrators usually issue an unbiased decision based on the evidence in each case as they strive to be fair and impartial in their decisions because they place a high value on their reputations.

The best explanation to the serious attention Russia appears to give to the appointment of arbitrators in ISDS is simple legitimacy. The right to choose and appoint an arbitrator is what distinctly positions arbitration within dispute settlement mechanisms including any national court system. This right is inherent to the legitimacy of an arbitral award. Thus, Russia views the potential reform of the appointment mechanism in this connection as irrational and unreasonable. 


\section{WiLl Russia ever Go to ICSID?}

The approach to international arbitration taken by Russia - the most economically and politically influential CIS member state - has been in a state of flux in recent years. ${ }^{109}$ Furthermore, the behaviour of Russia with respect to ratification demonstrates an unstable relationship with international regulatory framework. To illustrate, Russia ratified the New York Convention ${ }^{110}$ in 1960 and is a signatory to the Kiev Convention. ${ }^{111}$ Russia signed the ICSID Convention in 1992, but has not ratified it yet. Furthermore, while Russia is ignorant of the ICSID Convention, little mention (if any) is made about the exact origins of such ignorance. Likewise, although Russia signed the Energy Charter Treaty (ECT) ${ }^{112}$ in 1994, it withdrew from the Treaty in 2009 via an effective termination of the provisional application, stating its intent not to become an ECT Contracting Party. ${ }^{113}$ Arguably, this is a smart strategic move as the withdrawal triggered certain legal implications in the arbitration practice. Most notably, in Yukos Universal Limited v. Russia, the PCA award was revoked essentially because the ECT had not been ratified by the signatories. This meant that Russia was not bound by it. However, from 1994 to 2009, Russia applied the Treaty provisionally, albeit the application was fairly limited. Thus, notwithstanding its economic and political influence, "Russia has not developed as a major international arbitration jurisdiction." 114

One avenue, which Russia may rely on to develop as a major international arbitration jurisdiction is the ratification of the ICSID Convention. Nothing in the text of the ICSID Convention can be interpreted so as to put a State in a deliberately vulnerable position. Among other things, Article 25(4) provides an opportunity for a State at the time of ratification to specify "the class or classes of disputes" which could be submitted to the jurisdiction of the ICSID. This means that when joining the ICSID Convention Russia can choose at its own discretion and in its best national interests to narrow down the list of arbitrable disputes administered by ICSID. It is, however, a topic for a separate discussion whether such an opportunity can be used wisely, as may be questioned after the arbitration law reform in Russia which introduced in September 2016 a license regime for arbitration institutions willing to permanently arbitrate in Russia. ${ }^{115}$ As part of travaux préparatoires, in early 2014, the Russian Ministry of Justice proposed draft legislation designed "to make Russia a more attractive jurisdiction 
for international dispute resolution." "116 Yet, this draft legislation has been heavily criticised for, among other things, "failing to sufficiently narrow the scope of nonarbitrable disputes in Russia." 117

Some mention should also be made of Article 26 which allows a State to require the exhaustion of local remedies as a condition of its consent to arbitration under the ICSID Convention. This provision adds another layer of confidence for a State unwilling to submit exclusively to an international arbitral institution, despite the fact that the ICSID arbitral awards are commonly recognised as "more easily enforceable and predictable compared with other international tribunals." "118 For this reason alone, it is hard to conclude that the ICSID Convention can in any way jeopardise the position of a joining State. On the other hand, the ratification of the ICSID Convention could be problematic from the viewpoint of not being able to annul an award on the ground of public policy exception because the ICSID Convention does not include public policy exceptions to enforce an award. ${ }^{119}$ Elaborating on these propositions, so far Russia has not enforced a single arbitral award issued against it by an international investment tribunal.

The ICSID Convention has consistently attracted attention from major developed capital-exporting countries and developing capital-importing countries, with the most recent valuable addition to the ICSID system being Mexico. ${ }^{120}$ Not only does this reinforce the numerical and geographical expansion of the ICSID membership, but also indicates the truly adequate nature of the ICSID Convention. Furthermore, no political aspect, such as a potential constraint to state sovereignty, is a demotivating barrier in this context.

The motivations for the disinterest in the ratification of the ICSID Convention are somewhat unclear in light of recent developments in investment treaty policy of Russia. Back in 2001 the Government of the Russian Federation adopted the Russian Model BIT. ${ }^{121}$ Basically, it reiterates the common refrain of the replaced Model BIT of $1992 .{ }^{122}$ Yet, there were some novelties with respect to the dispute resolution mechanism. For instance, it introduced a landmark provision which recommended ICSID as an arbitral institution. Seemingly, this indicated a reviving interest in the ICSID membership, or a fragile willingness to start cooperation with ICSID. In practice, this means that foreign investors may have access to ICSID arbitration via the ICSID Additional Facility Rules. ${ }^{123}$ Here, it is explicitly allowed by investment treaties with those countries that have not ratified 
the ICSID Convention. Ironically, Russia, which is not a party to the ICSID Convention, agreed to use the ICSID Additional Facility Rules to resolve disputes by virtue of regional conventions. ${ }^{124}$

The BITs between Russia and China, Japan, Singapore, UAE, and more recently, Cambodia expressly provide that investors may submit disputes for ICSID arbitration. If so, can foreign investors from these countries submit disputes with Russia to ICSID? A simple answer is yes. These BITs provide that if the ICSID Convention is effective in both countries, investors may submit disputes to ICSID pursuant to the ICSID Convention; if it is not effective in either country, investors may choose to apply the ICSID Additional Facility Rules. ${ }^{125}$ It should be noted that the ICSID Additional Facility Rules arbitration is not as enforceable as ICSID arbitration pursuant to the ICSID Convention. However, "their awards are still more credible with more predictable results than other international investment arbitral awards." ${ }^{126}$ Unlike the ICSID awards, "awards rendered under the ICSID Additional Facility Rules are subject to the supervision of a national court, and their enforcement is covered by the New York Convention."

The new 2016 Regulation introduces a more stringent approach to some of the key provisions in a Russian Model BIT. The 2016 Regulation does not specify which international arbitration rules should be included in new investment treaties. In the meantime, it explicitly encourages selection of the UNCITRAL Arbitration Rules where a dispute is submitted to an ad hoc arbitration. ${ }^{128}$ These introductions mean that Russia might be willing to negotiate BITs which are more in line with the exact level of protection readily available to foreign investors in Russia. Consequently, investors could benefit from more certain protections than they currently have.

A common narrative assumes that access to ICSID arbitration is appealing to foreign investors and constitutes a motivating factor when planning investment paths. At present, there is no official position by Russia's authorities as to the ratification of the ICSID Convention. Whether or not Russia will ratify the ICSID Convention in the future, choosing a BIT that agrees on ICSID arbitration is good for protecting investors' interests. ${ }^{129}$ Naturally, a treaty-based recourse to arbitration under the ICSID Additional Facility Rules does not provide new guarantees to investors with respect to investment treaty arbitration. However, this ICSID-bound mechanism is still a welcoming shift in position. Russia seems to 
be flirting with the idea of becoming a full-time member of ICSID at some point which cultivates the perfect environment for the ICSID community to provoke negotiations with Russia on ICSID membership. In the long run, it takes two to tango.

\section{Conclusion}

Russia is a significant state in the UNCITRAL Working Group III and any slight shifts in its approach in the UNCITRAL reforms are closely watched. During the previous 34th and 35th meetings, Russia was very opposed to multilateral reform efforts and consistently downplayed the need for public law measures such as transparency and multilateral investment courts. Yet, the 36th meeting of the UNCITRAL in Vienna in October-November 2018 saw Russia less vocal and even silent on issues such as inconsistency. Whether Russia's position has softened or not, it is the right time to provide an analytical framework for understanding Russia's position in these reform dynamics.

Russia has an important voice in discussions, representing a major variation to the reform proponents. As one commentator noted, the bigger question is whether some of the states "that are less keen on a multilateral solution such as a multilateral investment court, will propose working on other options, such as a range of incremental reforms like developing a code of conduct or putting together a series of "best practices" on issues like multiple proceedings, non-disputing party submissions and frivolous claims." ${ }^{130}$ We conclude that Russia has not submitted any such proposals to date. Improving the regime requires great effort, a considerable amount of time, and even more patience. As the preceding discussion highlights, there are a number of competing considerations that need to be taken into account in determining whether, and to what extent, multilateral solutions should be implemented in the ISDS reform. Above all, improvements in the ISDS regime need to be in the interest of governments, both in their status as home and host states, and other key stakeholders, to give it the legitimacy and robustness that every international regime requires to be viable.

It would seem that discussing a reform within different dogmatic camps is like the men, in the old Buddhist parable asked to identify what animal is in a 
dark room. ${ }^{131}$ Each of them was allowed to touch only one part of an elephant. As accurate as each of the men may be in their individual study of a particular part, it is unlikely they will discover the true nature of the animal unless they compare notes and communicate.

To avoid this problem and more accurately gauge the true nature of the ISDS reform, the Working Group III delegates should communicate their reform proposals as to the desired directions of a single reform or a suite of reforms. The broader implication of this discussion is that the current approach to the ISDS reform, which is largely chaotic and uncoordinated, is not satisfactory to capture the range of issues that are involved. This article has studied Russia's stance in the UNCITRAL Working Group III to push back on the misperception that Russia is opposed to reform as such, and it has reveals doctrinal implications about its behaviour.

Finally, by adding ICSID considerations, this article aims not to issue a final statement or make projections (which is always hard and not always reliable) about Russia's approach toward the ratification of the ICSID Convention, but rather to spark a renewed, more nuanced discussion of Russia's foreign investment policy and national and international actors that shape it.

\section{REFERENCES}

1. United Nations Commission on International Trade Law.

2. See, e.g., J. Arato, A Watershed Moment for ISDS Reform, International Economic Law and Policy Blog (Nov. 4, 2018), available at https://worldtradelaw.typepad. com/ielpblog/2018/11/a-watershed-moment-for-isds-reform.html\#_edn1; A. Roberts, UNCITRAL and ISDS Reforms: Moving to Reform Options... the Process, EJIL: TALK! (Nov. 7, 2018), available at https://www.ejiltalk.org/uncitral-and-isds-reforms-movingto-reform-options-the-process/\#more-16626; A. Roberts \& Z. Bouraoui, UNCITRAL and ISDS Reforms: What are States' Concerns?, EJIL: TALK! (June 5, 2018), available at https://www.ejiltalk.org/uncitral-and-isds-reforms-what-are-states-concerns; A. Roberts \& Z. Bouraoui, UNCITRAL and ISDS Reforms: Concerns about Consistency, Predictability and Correctness, EJIL: TALK! (June 5, 2018), available at https://www.ejiltalk.org/ uncitral-and-isds-reforms-concerns-about-consistency-predictability-and-correctness; A. Roberts \& Z. Bouraoui, UNCITRAL and ISDS Reforms: Concerns about Arbitral 
Appointments, Incentives and Legitimacy, EJIL: TALK! (June 6, 2018), available at https://www.ejiltalk.org/uncitral-and-isds-reforms-concerns-about-arbitral-appointmentsincentives-and-legitimacy; A. Roberts \& Zeineb Bouraoui, UNCITRAL and ISDS Reforms: Concerns about Costs, Transparency, Third Party Funding and Counterclaims, EJIL: TALK! (June 6, 2018), available at https://www.ejiltalk.org/uncitral-and-isds-reformsconcerns-about-costs-transparency-third-party-funding-and-counterclaims; A. Grill, Mind the Label: Loyalists and Reformists and ISDS, Kluwer Arbitration Blog (Dec. 29, 2017), available at $\mathrm{http}$ ://arbitrationblog.kluwerarbitration.com/2017/12/29/uncitral-isds-workinggroup-vienna-11-12-2017.

3. Audio Recordings, UNCITRAL, available at https:/uncitral.un.org/en/audio.

4. A. Bianchi, On Power and Illusion: The Concept of Transparency, in International Law in Transparency in International Law 1 (A. Bianchi \& A. Peters eds., 2013).

5. A. Saravanan \& S. Subramanian, Transparency and Confidentiality Requirements in Investment Treaty Arbitration, 5:4 BRICS L. J. 115 (2018).

6. R. Dolzer \& Ch. Schreuer, Principles of International Investment Law 133 (2008).

7. UNCITRAL, Rep. of Working Group III (ISDS) on the work of its thirty-fourth session, pt. I, 12, U.N. Doc. A/CN.9/930/Rev.1 (Dec. 19, 2017).

8. Supra note 7, at 13.

9. U.N. Doc. A/CN.9/WG.III/WP.142.

10. Investment Dispute Settlement Navigator, UNCTAD, available at https://investmentpolicy. unctad.org/investment-dispute-settlement.

11. United Nations Commission on International Trade Law Rules on Transparency in Treatybased Investor-State Arbitration and Arbitration Rules (as revised in 2010, with new Article 1, paragraph 4, as adopted in 2013), art. 34(5) (Dec. 16, 2013), U.N. Doc. G.A. Res. 68/109.

12. Cesare Galdabini SpA v. The Russian Federation, Award (May 1, 2011), available at https://www.italaw.com/cases/236.

13. Luxtona Limited v. The Russian Federation, available at https://www.italaw.com/ cases/6625.

14. Oschadbank v. The Russian Federation, PCA Case Repository No. 2016-14, available at https://www.italaw.com/cases/7491.

15. Yukos Universal Limited (Isle of Man) v. The Russian Federation, PCA Case Repository No. 2005-04/AA227, available at https://www.italaw.com/cases/1175.

16. PJSC CB PrivatBank and Finance Company Finilon LLC v. Russian Federation, PCA Case Repository No. 2015-21, available at https://www.italaw.com/cases/3970.

17. S. Paushok, CJSC Golden East Company and CJSC Vostokneftegaz Company v. The Government of Mongolia, ICSID Case No. ARB/98/4, Award on Jurisdiction and Liability, (Apr. 28, 2011), available at https://www.italaw.com/sites/default/files/casedocuments/ita0622.pdf. 
18. Oleg Deripaska v. The Republic of Montenegro, PCA Case Repository No. 2017-07, available at $\mathrm{https} / / / \mathrm{www}$.italaw.com/cases/4785.

19. See, e.g., Ministry of Land and Property of the Republic of Tatarstan v. Ukraine (2016), available at https://investmentpolicy.unctad.org/investment-dispute-settlement/cases/763/ tatarstan-v-ukraine; Roscosmos State Corporation for Space Activities, RKTs Progress, KBOM and TsENKI v. French Republic, Case No. 16/01314, available at https://www. italaw.com/cases/4422; Ms. Olga Ovchinnikova v. Kingdom of Sweden (2016), available at https://www.italaw.com/cases/4365.

20. International Centre for Settlement of Investment Disputes.

21. Emergofin B.V. and Velbay Holdings Ltd. v. Ukraine, ICSID Case No. ARB/16/35, available at https://www.italaw.com/cases/4430. In this case, two subsidiaries of the Russian aluminium producer Rusal, Emergofin BV and Velbay Holdings, incorporated in the Netherlands and Cyprus respectively, filed a request for ICSID arbitration against Ukraine under Article 9 of the Netherlands-Ukraine BIT.

22. UNCITRAL Rules on Transparency in Treaty-based Investor-State Arbitration, available at https://www.uncitral.org/pdf/english/texts/arbitration/rules-on-transparency/Rules-onTransparency-E.pdf.

23. So far, five States have ratified the Convention including Cameroon, Canada, Gambia, Mauritius, and Switzerland.

24. Regulation on Entering into International Treaties on the Encouragement and Mutual Protection of Investments (No. 992 Regulation of The Russian Federation, Sept. 30, 2016).

25. See generally C. Buys, The Tensions between Confidentiality and Transparency in International Arbitration, 14 Am. Rev. Int'L Arb. 121 (2003).

26. For a more substantial analysis, see S. Kochevar, Amici Curiae in Civil Law Jurisdictions, 122 YALE L. J. 1653 (2013).

27. E. de Brabandere, NGOs and the "Public Interest": The Legality and Rationale of Amicus Curiae Interventions in International Economic and Investment Disputes, 12 CHI. J. INT'L L. 86-7 \& 94 (2011).

28. Saravanan A \& S. Subramanian, The Participation of Amicus Curiae in Investment Treaty Arbitration, 5:4 J. Civil \& Legal Services (2016).

29. L. Vierucci, NGOs Before International Courts and Tribunals, in NGOs IN INTERNATIONAL Law: Efficiency in Flexibility? 160 (P. Dupuy \& L. Vierucci eds., 2008).

30. L. Bartholomeusz, The Amicus Curiae before International Courts and Tribunals, 5 NonSt. Actors \& InT'L L. 211 (2005).

31. Id.

32. Id.

33. E. Levine, Amicus Curiae in International Investment Arbitration, 29 Berkeley J. INT'L L. 208 (2011). 
34. S. Krislov, The Amicus Curiae Brief: From Friendship to Advocacy, 72 Yale L. J. 704 (1963).

35. Supra note 33, at 208.

36. Aguas del Tunari, S.A. v. Republic of Bolivia, ICSID Case No. ARB/02/3, Decision on Respondent's Objections to Jurisdiction (Oct. 21, 2005), available at https://www.italaw. $\mathrm{com} /$ sites/default/files/case-documents/italaw10957_0.pdf.

37. Supra note 33, at 208.

38. Id. at 200.

39. Id. See also B. Choudhury, Recapturing Public Power: Is Investment Arbitration's Engagement of the Public Interest Contributing to the Democratic Deficit?, 41VAND. J. Transnat'l L. 775 (2008); A. Newcombe \& A. Lemaire, Should Amici Curiae Participate in Investment Treaty Arbitrations?, 5 Vindobona J. InT'L Comm. L. \& ARB. 22 (2001).

40. S. Lamb et al., Recent Developments in the Law and Practice of Amicus Briefs in Investor-State Arbitration, 5:2 InD. J. ARB. L. 90 (2017).

41. Supra note 27, at 112.

42. Suez, Sociedad General de Aguas de Barcelona, S.A. and Vivendi Universal, S.A. v. Argentine Republic, ICSID Case No. ARB/03/19, Order in response to a Petition for Participation as Amicus Curiae, $\mathbb{1} 13$ (May 19, 2005).

43. Supra note 27, at 106.

44. Id. at 110 .

45. Id. at 106 .

46. Id. at 111 .

47. Id.

48. Eli Lilly and Company v. The Government of Canada, ICSID Case No. UNCT/14/2, Procedural Order No. 4 (Feb. 23, 2016).

49. Id. at Respondent's Observations on Non-Disputing Party Applications (Feb. 19, 2016).

50. Supra note 40, at 82-3.

51. Supra note 42. See also Biwater Gauff (Tanzania) Ltd. v. United Republic of Tanzania, ICSID Case No. ARB/05/22, Award (July 24, 2008).

52. Supra note 27, at 102.

53. A. Bjorklund, The Emerging Civilization of Investment Arbitration, 113:4 PenN ST. L. REv. 1290-94 (2009).

54. D. Esty, Good Governance at the Supranational Scale: Globalizing Administrative Law, 115 Y ALE L. J. 1546 (2006). (identifying amicus briefs at the WTO as "a new avenue for participation").

55. Id. See also R. Stewart \& M. Badin, The World Trade Organization: Multiple Dimensions of Global Administrative Law, 9 InT'L J. Const. L. 582 (2011). ("The Appellate Body's embrace of amicus briefs reflects the adoption of global administrative law to boost 
organizational legitimacy...").

56. See, e.g., Dispute Settlement Body Special Session, Taiwan, Penghu, Kinmen \& MatsuDOHA Mandated Review of the Dispute Settlement Understanding (DSU), WTO Doc. TN/DS/W/25, at 2 (Nov. 27, 2002). ("To allow unsolicited amicus curiae submissions... would create a situation where those Members with the least social resources could be put at a disadvantage."); Dispute Settlement Body Special Session, Cuba, Honduras, India, Malaysia, Pakistan, Sri Lanka, Tanzania \& Zimbabwe - Negotiations on the Dispute Settlement Understanding, WTO Doc. TN/DS/W/18, at 4 (Oct. 7, 2002) ("If ... nongovernmental entities were allowed to influence the process and outcome of disputes, it would severely erode the Member governments' authority and ability to participate effectively in the dispute settlement process."); Statement by Uruguay at the General Council, Decision by the Appellate Body Concerning Amicus Curiae Briefs, WTO Doc. WT/GC/38 at 3 (Dec. 4, 2000). (arguing that acceptance of amicus briefs inappropriately altered the dispute settlement mechanism and limited the rights of parties to a dispute).

57. This controversial correlation is known as the "legal origins thesis." See, e.g., V. Curran, Comparative Law and the Legal Origins Thesis: "[N]on scholae sed vitae discimus," 57:4 Ам. J. Сомр. L. 865 (2009). ("The legal origins thesis ... contrasts countries with common and civil law origins, correlating common law origins with ... greater economic well-being.").

58. Supra note 53, at 1293.

59. Supra note 40 , at 85 .

60. Id.

61. Methanex Corp. v. U.S.A., Decision of the Tribunal on Petitions from Third Persons to Intervene as "Amici Curiae" (Jan. 15, 2001), available at https:/www.italaw.com/sites/ default/files/case-documents/ita0517_0.pdf. (The NGOs eventually submitted amicus briefs on the basis of the NAFTA FTC Statement - Final Award of the Tribunal on Jurisdiction and Merits, 3 August 2005, ๆๆ 26-30, pt. II, ch. C).

62. Pac Rim Cayman LLC v. The Republic of El Salvador, ICSID Case No. ARB/09/12, Award (Oct. 14, 2016).

63. Supra note 40 , at 85.

64. Biwater Gauff (Tanzania) Ltd., supra note 52.

65. Philip Morris Brands Sàrl, Philip Morris Products S.A. and Abal Hermanos S.A. v. Oriental Republic of Uruguay, ICSID Case No. ARB/10/7, Award (July 8, 2016).

66. Id. at 9 ๆ 389-410.

67. Supra note 40 , at 87.

68. Id. at 86 .

69. Id.

70. See, e.g., Electrabel S.A. v. Republic of Hungary, ICSID Case No. ARB/07/19, Award (Nov. 25, 2015); Ioan Micula, Viorel Micula, S.C. European Food S.A, S.C. Starmill 
S.R.L. and S.C. Multipack S.R.L. v. Romania [I], ICSID Case No. ARB/05/20, Final Award (Dec. 11, 2013).

71. Supra note 40 , at 91.

72. D. Shelton, The Participation of Nongovernmental Organizations in International Judicial Proceedings, 88:4 Am. J. INT'L L. 612 (1994).

73. Id.

74. C. Rogers, Transparency in International Commercial Arbitration, 54 U. Kan. L. Rev. 1301 (2006).

75. J. Hope, Transparency in International Arbitration, Commercial Dispute Resolution, Comm. Disp. Res. News, May 11, 2016, available at https://www.cdr-news.com/ categories/expert-views/6376-transparency-in-international-arbitration.

76. Supra note 40, at 91.

77. For details, see 2018 International Arbitration Survey: The Evolution of International Arbitration conducted by the School of International Arbitration, Queen Mary University of London (QMUL) in partnership with White \& Case LLP; White \& Case, 2018 International Arbitration Survey: The Evolution of International Arbitration (May 9, 2018), http:/www.arbitration.qmul.ac.uk/media/arbitration/docs/2018-InternationalArbitration-Survey-report.pdf.

78. S. Schill, $W(h)$ ither Fragmentation? On the Literature and Sociology of International Investment Law, 22 EuR. J. INT'L L. 887 (2001).

79. Id.

80. J. Weiler, The Rule of Lawyers and the Ethos of Diplomats, 35:2 J. WorLd Trade 194-7 (2001).

81. Supra note 78 , at 888 .

82. B. Legum, Investment Treaty Arbitration's Contribution to International Commercial Arbitration, 60 Disp. Res. J. 73 (2005). See also A. Bjorklund, Private Rights and Public International Law: Why Competition among International Economic Law Tribunals Is Not Working, 59 Hastings L. J. 251 (2007).

83. Mistelis, Confidentiality and Third-Party Participation: UPS v. Canada and Methanex Corp. v. USA, in International InVESTMENT Law AND Arbitration 169 (May, 2005).

84. UNCITRAL Arbitration Rules, art. 32(5), U.N. G.A. Res. A/65/465 (Dec. 6, 2010).

85. Supra note 33, at 204.

86. Convention on the Settlement of Investment Disputes between States and Nationals of Other States art. 48(5), Oct. 14, 1966, 575 U.N.T.S. 159 (hereinafter ICSID Convention).

87. Supra note 33, at 204.

88. Supra note 78 , at 889.

89. Id.

90. Tribunals presided over by public international lawyers, e.g., appear to make reference more frequently to decisions by the ICJ or the PCIJ than tribunals presided over by 
commercial arbitrators. See supra note 78 , at 889.

91. T. Wälde, Interpreting Investment Treaties: Experiences and Examples, in INTERNATIONAL Investment Law for the 21st Century - Essays in Honour of Christoph Schreuer 724 (2009).

92. S. Schill, Crafting the International Economic Order: The Public Function of Investment Treaty Arbitration and Its Significance for the Role of the Arbitrator, 23 LEIDEN J. INT'L L. 401 (2010).

93. For details, see D. Labin \& A. Soloveva, International Investment Law as International Law: Russian and Western Approaches, 112 AJIL UnBound 202 (2018).

94. Recording: UN Comm'n. on Int'1 Trade Law, 34th Sess. (Nov. 27 - Dec. 1, 2017), available at $\mathrm{http} / / \mathrm{www}$.uncitral.org/uncitral/audio/meetings.jsp.

95. A. Roberts, Incremental, Systemic, and Paradigmatic Reform of Investor-State Arbitration, 112:3 Am. J. InT'L. L. 410 (2018).

96. Id.

97. IIA Issues Note - Issue 1, Reforming Investment Dispute Settlement: A Stocktaking UNCTAD (Mar. 2019), available at https:/unctad.org/en/PublicationsLibrary/diaepcbinf 2019d3_en.pdf.

98. Id.

99. Supra note 95 , at 415 .

100. A. Roberts \& Z. Bouraoui, UNCITRAL and ISDS Reforms: Concerns About Consistency, Predictability and Correctness, EJIL: TALK! (June 5, 2018), available at https://www.ejiltalk.org/uncitral-and-isds-reforms-concerns-about-consistencypredictability-and-correctness.

101. K. Sauvant, Lessons from the negotiations of the United Nations Code of Conduct on Transnational Corporations and related instruments, in Alternative Visions OF THE International Law on Foreign Investment: Essays in Honour of Muthucumaraswamy SoRnARAJAH 192 (C. Lim ed., 2016).

102. Recording: UN Comm'n. on Int'1 Trade Law, 35th Sess. (Apr. 23-27, 2018), available at http://www.uncitral.org/uncitral/audio/meetings.jsp.

103. Supra note 94; supra note 102.

104. UN Comm'n on Int'l Trade Law, 36th Sess. (Oct. 29 - Nov. 2, 2018), available at http:// www.uncitral.org/uncitral/audio/meetings.jsp.

105. S. Blythe, The Advantages of Investor-State Arbitration as a Dispute Resolution Mechanism in Bilateral Investment Treaties, 47 INT'L LAw. 278 (2013).

106. J. Alvarez, Recent Book on International Law: Book Review, 102 Am. J. InT'L L. (2008) (reviewing Gus van Harten, Investment Treaty Arbitration and Public Law (2007)).

107. D. Kapeliuk, The Repeat Appointment Factor: Exploring Decision Patterns of Elite Investment Arbitrators, 96 CORNELL L. Rev. 89-90 (2010).

108. Supra note 105, at 278. 
109. S. Finizio \& K. Beale, Russian Arbitration Reforms. Repatriating Russian disputes, 5 Comm. Disp. Res. 21 (2014).

110. United Nations Convention on the Recognition and Enforcement of Foreign Arbitral Awards (June 10, 1958), U.N. Doc. E/CONF.26/8Rev.1.

111. Kiev Convention on Settling Disputes Related to Commercial Activities (Mar. 20, 1992), available at http://cisarbitration.com/wp-content/uploads/2017/02/KievConvention-on-Settling-Disputes-Related-to-Commercial-Activities-russian.pdf.

112. Energy Charter Treaty (December 17, 1994), I-36116 https://treaties.un.org/Pages/ UNTSOnline.aspx?id=2\&clang=_en.

113. For details, see I. Mironova, Russia and the Energy Charter Treaty, International Energy Charter (Aug. 7, 2014), available at https://energycharter.org/what-we-do/knowledgecentre/occasional-papers/russia-and-the-energy-charter-treaty.

114. Supra note 109 , at 21.

115. Federal Law On Arbitration Proceedings (Arbitration Courts) in the Russian Federation (No. 382-FZ, Dec. 29, 2015) (Russia); Federal Law on Amendments to Certain Legislative Acts of the Russian Federation and Repeal of Article 6.1 (3) of the Federal Law on Self-Regulating Organization in Connection with the Adoption of the Federal Law on Arbitration Proceedings (Arbitration Courts) in the Russian Federation (No. 409-FZ, Dec. 29, 2015).

116. Supra note 109 , at 21.

117. Id.

118. T. Wenjing, Investing in Russia?-Lessons learnt from the Yukos and Sanum Cases, Lexology China L. Insight, Mar. 24, 2017, available at https://www.lexology.com/ library/detail.aspx?g=bfbafe0f-1486-429f-99a9-cedf908adaaa.

119. ICSID Convention, arts. 50-52.

120. Mexico signed the International Centre for Settlement of Investment Disputes (ICSID) Convention last January 11, 2018. Upon the Senate's approval of the Convention, Mexico's president published the instrument in Mexico's Public Gazette (Diario Oficial de la Federación) and submitted the ratification instrument to ICSID on July 27, 2018. As a result, based on Article 68(2) of the ICSID Convention, this instrument formally came into force for Mexico on August 26, 2018. With Mexico, there are now 162 signatory states of the ICSID Convention, and 154 members.

121. Decree of the Government of the Russian Federation on Entering into International Treaties on the Encouragement and Mutual Protection of Investments between the Government of the Russian Federation and the Governments of Foreign States (Collection of Russian Federation Legislation, June 18, 2001, No. 25. at 2578).

122. Decree of the Government of the Russian Federation No. 395 (June 11, 1992).

123. Adopted on Sept. 27, 1978.

124. See, e.g., CIS (Moscow) Convention for the Protection of Investors' Rights 1997; 
EurAsEc Convention for the Promotion and Mutual Protection of Investments 2008; Treaty on the Eurasian Economic Union 2014.

125. China-Russian Federation BIT 2006, art. 9(1)(b).

126. Supra note 118.

127. Y. Kryvoi, Ratification of Arbitration-Related Conventions by CIS States: Global and Regional Framework, CIS ARв. F., May 18, 2018, available at http://www. cisarbitration.com/2018/05/18/ratification-of-arbitration-related-conventions-by-cisstates-global-and-regional-framework.

128. Addendum 2 to the Regulation 2016, art. 53.

129. Supra note 118.

130. A. Roberts, UNCITRAL and ISDS Reforms: Moving to Reform Options ... the Process, EJIL: TALK! (Nov. 7, 2018), available at https://www.ejiltalk.org/author/aroberts.

131. E. Goldste, Blind men and an elephant, in Encyclopedia of Perception 492 (2010). 